\title{
PENGARUH PENERAPAN PENDEKATAN KONTEKSTUAL TERHADAP KEMAMPUAN BERPIKIR KRITIS MATEMATIS SISWA SMP
}

\section{Usep Suwanjal}

\author{
SMK Negeri 1 Menggala Tulang Bawang \\ Email : usep.suwanjal@gmail.com
}

\begin{abstract}
Critical thinking skills of mathematics mastered by students is very important, especially in the competition of globalitation era. An approach that can improve both of them is contextual approach in learning. This research aims are to determine: The Improvement of students' critical thinking skills between the class which used contextual approach in learning and the one which used conventional learning. Quasi-experiment methods was used in the research and the design was "pretest-posttest non equivalent control group". Population of this research was the students of SMP Negeri 3 Menggala and class VIII $C$ and VIII D as the research sample, technique of samples used purposive sampling. Data collected by the instrument test critical thinking of mathematics. The improvement of critical thinking skills data analysed by using the t- test. The findings of this study indicated: The Improvement of students' critical thinking skills between the class which used contextual approach in learning was better than which used conventional learning. In table t-test indicated sig $<\alpha$ is $0.001<0.05$
\end{abstract}

Keywords : contextual approach, critical thinking skills of mathematics

\section{PENDAHULUAN}

Pada masa sekarang ini, perkembangan Ilmu Pengetahuan dan Teknologi atau IPTEK membawa perubahan pada setiap bagian kehidupan manusia dan berbagai macam permasalahan yang timbul dari perubahan tersebut hanya dapat dipecahkan dengan penguasaan IPTEK. Maka dari itu diperlukan kemampuan untuk mendapatkan, mengelola dan memanfaatkan IPTEK sebagai upaya untuk bertahan pada keadaan yang selalu berubah ini. Kemampuan tersebut hendaknya mengembangkan kemampuan berpikir kritis, logis, sistematis, dan kemampuan ini dapat dikembangkan dalam pembelajaran matematika.

Matematika merupakan salah satu mata pelajaran yang memiliki peranan penting dalam ilmu pengetahuan, sehingga mata pelajaran ini diajarkan dari jenjang pendidikan dasar hingga perguruan tinggi. Pembelajaran matematika 
akan terlaksana dengan baik apabila setiap siswa memiliki kemampuan matematis. Dalam National Council of Teachers of Matematics atau NCTM (2000), dirumuskan lima kemampuan matematis yang harus dikuasai oleh siswa diantaranya kemampuan komunikasi, penalaran, pemecahan masalah, koneksi dan sikap positif terhadap matematika. Sejalan dengan NCTM itu, dalam KTSP (Depdiknas, 2006) juga dirumuskan lima kemampuan matematis yang harus dimiliki siswa yaitu pemahaman konsep, penalaran, komunikasi, pemecahan masalah dan representasi matematis.

Sesuai dengan rumusan standar di atas salah satu kemampuan yang harus dikuasai oleh siswa yaitu kemampuan berpikir kritis. Kemampuan berpikir kritis dan kreatif yang dikuasai siswa merupakan hal yang sangat penting, karena permasalahan yang terjadi juga semakin kompleks. Berpikir kritis adalah kemampuan menafsirkan, menganalisis terhadap informasi yang diterima, diperiksa kebenarannya sehingga seseorang tersebut mampu memberikan kesimpulan terhadap informasi tersebut dengan alasan yang tepat.

Berkaitan dengan berpikir kritis, kenyataan yang tidak dapat dihindari adalah masih banyak siswa yang menganggap matematika adalah mata pelajaran yang sulit dan susah untuk dipahami. Rendahnya kemampuan berpikir kritis terungkap dari hasil penelitian Syahbana (2012: 46) bahwa sekolah justru mendorong siswa memberi jawaban yang benar daripada mendorong mereka memunculkan ide-ide baru atau memikirkan ulang kesimpulankesimpulan yang sudah ada. Dari hal tersebut mengakibatkan lulusan siswa sekolah hanya memiliki kemampuan yang tidak mendalam terhadap ilmu pengetahuan.

Berdasarkan hasil temuan tersebut, kegiatan di atas sesuai dengan kebiasaan pembelajaran konvensional. Pada pembelajaran konvensional kegiatan pembelajaran guru selalu menjelaskan, memberi contoh soal, memberikan latihan, dan seluruh kegiatan berpusat kepada guru. Siswa hanya menerima informasi satu arah, hanya dari guru saja sehingga ide siswa tidak muncul, mengakibatkan kemampuan berpikir kritis siswa tidak mengalami peningkatan.

Dalam proses belajar guru harus merangsang siswanya untuk belajar aktif, sehingga siswa dapat menggali, mengembangkan kemampuan yang telah dimiliki dan dapat memanfaatkan lingkungan sebagai sumber belajar dengan bantuan guru sebagai fasilitator. Menurut Vygotsky (dalam Sutawidjaja dan Afgani, 2011: 1.4) berpendapat bahwa proses belajar akan terjadi secara 
efisien dan efektif apabila anak belajar secara kerjasama dengan anak-anak lain dalam suasana dan lingkungan yang mendukung, dalam bimbingan seseorang yang lebih mampu, guru atau orang dewasa.

Berdasarkan teori belajar di atas, agar proses pembelajaran dapat berlangsung dengan baik, maka diperlukan beberapa aspek untuk mendukung pembelajaran tersebut. Oleh karena itu untuk menumbuhkan kemampuan berpikir kritis matematis siswa diperlukan pendekatan yang mampu mengebangkan kemampuan tersebut. Salah satu pendekatan dalam proses pembelajaran yang dapat digunakan adalah pendekatan kontekstual. Pendekatan kontekstual adalah konsep belajar yang membantu guru mengaitkan antara materi yang diajarkannya dengan situasi dunia nyata siswa dan mendorong siswa membuat hubungan antara pengetahuan yang dimilikinya dengan penerapannya dalam kehidupan mereka sehari-hari.

Berdasarkan uraian diatas, maka dapat dirumuskan masalah penelitian adalah apakah peningkatan kemampuan berpikir kritis siswa yang memperoleh pembelajaran dengan pendekatan kontekstual lebih baik dari pada siswa yang mendapatkan pembelajaran secara konvensional?.

\section{METODE PENELITIAN}

Metode penelitian kuasi eksperimen dengan menggunakan desain penelitian berbentuk "pretest-postest non equivalent control group. Sebelum mendapatkan perlakuan, diberikan pretes dan setelah mendapatkan perlakuan diberikan postes. Juandi \& Sugilar (2011: 9.10) memberikan bentuk desain pada penelitian ini sebagai berikut.

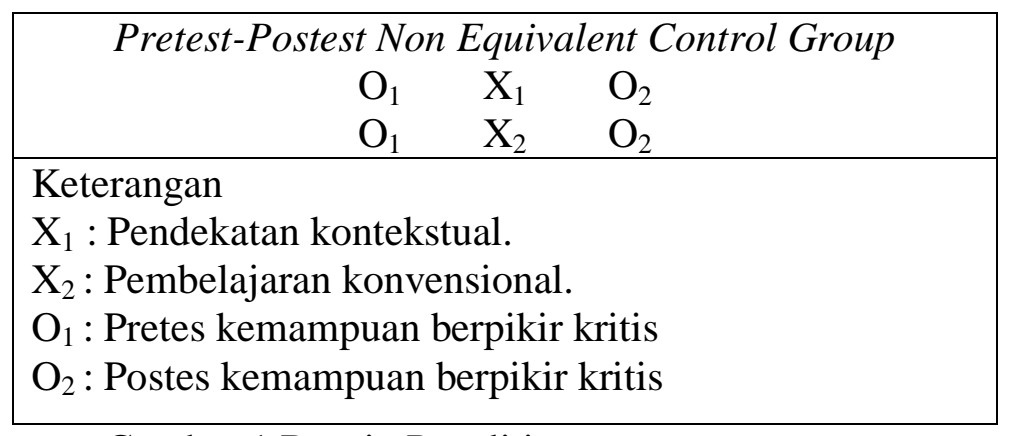

Gambar 1 Desain Penelitian 
Penelitian ini dilaksanakan pada siswa Sekolah Menengah Pertama. Populasi penelitian ini adalah seluruh siswa SMP Negeri 3 Menggala dengan sampel penelitian adalah siswa kelas VIII. Teknik sampel yang digunakan purposive sampling, terpilih kelas VIII C sebagai kelas eksperimen dan VIII D sebagai kelas kontrol.

Tes kemampuan berpikir kritis yang digunakan berbentuk uraian. Dalam penyusunan tes, diawali dengan penyusunan kisikisi yang mencakup kompetensi dasar, indikator, aspek yang diukur beserta penilaiannya dan nomor butir soal. Jumlah soal yang digunakan untuk mengetahui kemampuan berpikir kritis siswa berjumlah 5 soal pretes dan postes.

Setelah data kemampuan berpikir kritis matematis siswa pretes, postes dan gain ternormalisasi $(N$-Gain $)$ terkumpul, maka akan dilakukan analisis statistik dengan bantuan program SPSS for Windows. Interpretasi gain ternormalisasi menurut Meltzer (dalam Wiliyati, 2012) sebagai berikut: $0<g \leq$ 0,3 (rendah), $0,3 \leq g<$ 0,7 (sedang), $1 \geq g>$ 0,7 (tinggi).

\section{HASIL PENELITIAN DAN PEMBAHASAN}

Berikut ini disajikan Tabel 1 yang berisikan data skor pretes, postes, dan gain ternormalisasi $(N$ Gain) kemampuan berpikir kritis yang terdiri dari skor tertinggi, skor terendah, skor rata-rata dan standar deviasi.

Tabel 1. Statistik Deskriptif Skor Kemampuan Berpikir Kritis

\begin{tabular}{|c|c|c|c|c|c|c|c|c|c|c|}
\hline \multirow{2}{*}{ Tes } & \multicolumn{4}{|c|}{ Kelas Eksperimen } & \multicolumn{5}{c|}{ Kelas Kontrol } \\
\cline { 2 - 11 } & $N$ & $\begin{array}{c}\mathrm{X} \\
\min \end{array}$ & $\mathrm{X}_{\max }$ & $\bar{X}$ & $S$ & $N$ & $\mathrm{X}_{\min }$ & $\mathrm{X}_{\max }$ & $\bar{X}$ & $S$ \\
\hline Pretes & 26 & 2 & 13 & 6,92 & 3,071 & 26 & 3 & 14 & 8,08 & 2,682 \\
\hline Postes & 26 & 2 & 15 & 10,50 & 2,534 & 26 & 5 & 15 & 9,85 & 2,493 \\
\hline N-Gain & - & - & - & 0,456 & - & - & - & - & 0,244 & - \\
\hline
\end{tabular}

Tabel 1 memperlihatkan rerata gain ternormalisasi kelas eksperimen sebesar 0,456 lebih tinggi daripada rerara gain ternormalisasi kelas kontrol sebesar 0,244 dengan perbedaan sebesar 0,212. Secara umum, seperti diperlihatkan pada Tabel 1 bahwa rataan skor kemampuan berpikir kritis siswa kelas eksperimen menunjukkan kenaikan sebesar 3,58 lebih besar dari kelas kontrol yang hanya sebesar 1,77 .

Dari uji perbedaan rata-rata diperoleh Sig rerata kemampuan berpikir kritis matematis siswa eksperimen dan siswa kelas 
kontrol adalah $0,001<0,05=\alpha$, maka hipotesis $H_{0}$ ditolak. Sehingga dapat disimpulkan bahwa rerata peningkatan kemampuan berpikir kritis siswa yang memperoleh pembelajaran dengan pendekatan kontekstual lebih baik daripada rerata peningkatan kemampuan berpikir kritis siswa yang memperoleh pembelajaran konvensional.

Analisis data hasil penelitian menunjukkan bahwa kemampuan berpikir kritis siswa dengan pembelajaran kontekstual lebih baik daripada pembelajaran konvensional. Secara umum, seperti diperlihatkan pada Tabel 1 bahwa rataan skor kemampuan berpikir kritis siswa kelas eksperimen menunjukkan kenaikan sebesar 3,58 lebih besar dari kelas kontrol yang hanya sebesar 1,77. Dan hasil dari gain ternormalisasi

$(N-$ Gain $)$

kemampuan berpikir kritis kelas eksperimen menunjukkan hasil sebesar 0,456, menurut interpretasi nilai tersebut berarti mengalami peningkatan sedang. Sedangkan hasil dari gain ternormalisasi $(N$ Gain) kemampuan berpikir kritis kelas kontrol menunjukkan hasil sebesar 0,244, yang berarti mengalami peningkatan rendah. Hasil temuan tersebut mengidentifikasi bahwa belajar matematika dengan pembelajaran kontekstual memberikan pengaruh positif terhadap kemampuan berpikir kritis siswa.
Peningkatan kemampuan berpikir kritis dipengaruhi oleh beberapa faktor diantaranya adalah faktor pembelajaran yang digunakan guru dalam melaksanakan kegiatan pembelajaran dan faktor dari diri siswa. Peningkatan kemampuan berpikir kritis terjadi tidak hanya pada siswa yang memperoleh pembelajaran kontekstual tetapi peningkatan tersebut juga terjadi pada siswa yang memperoleh pembelajaran konvensional.

Peningkatan kemampuan berpikir kritis melalui pendekatan kontekstual lebih baik daripada pembelajaran konvensional, dikarenakan siswa yang belajar dengan pendekatan kontekstual menjadikan pengalaman lebih bermakna bagi mereka dalam membangun pengetahuan yang akan mereka terapkan dalam pembelajaran sehari-hari. Dan guru mendesain pembelajaran sebagai sebuah sistem mengajar, didasarkan pemikiran bahwa kebermaknaan belajar yang muncul sebagai akibat dari hubungan antara isi dengan konteksnya. Semakin banyak keterkaitan dalam konteks yang luas maka semakin bermaknalah isi pemikiran siswa. Sehingga dengan pembelajaran kontekstual siswa terarah untuk melakukan proses berpikir kritis.

Berdasarkan uraian diatas, peningkatan kemampuan berpikir kritis didukung oleh beberapa komponen 
\begin{tabular}{llr} 
kontekstual & yang & dalam \\
penerapannya & dilakukan & oleh \\
siswa dengan & bimbingan & guru \\
diantaranya & \multicolumn{2}{c}{ Kontruktivisme }
\end{tabular} (contructivism) yaitu pengetahuan dibangun oleh siswa itu sendiri melalui keterlibatan aktif dalam proses belajar, yang hasilnya diperluas melalui konteks yang lebih sederhana. Bertanya (questioning) pada saat proses bertanya guru membimbing, mendorong dan menilai kemampuan berpikir siswa dalam menyerap pengetahuan. Dan inkuiri guru membimbing siswa dalam menemukan dengan cara mengamati, melalukan observasi, bertanya, mengajukan dugaan, mengumpulkan data dan pada akhirnya menyimpulkan hasil temuan.

\section{KESIMPULAN DAN SARAN}

Peningkatan kemampuan berpikir kritis antara siswa yang memperoleh pembelajaran dengan pendekatan kontekstual lebih baik daripada siswa yang memperoleh pembelajaran secara konvensional. Untuk menerapkan pembelajaran kontekstual, sebaiknya guru telah membuat sebuah skenario dan perencanaan yang tepat sesuai dengan karekteristik pembelajaran kontekstual, sehingga pembelajaran dapat terlaksana dengan baik sesuai dengan tujuan yang diharapkan yaitu peningkatan kemampuan berpikir kritis matematis siswa. Sebaiknya guru dalam proses kegiatan belajar mengajar perlu mempertimbangkan antara lain pemilihan pokok bahasan yang relevan dengan konteks sehari-hari atau berkaitan dengan hal-hal dalam dunia nyata mereka.

\section{DAFTAR PUSTAKA}

Departemen Pendidikan Nasional Republik Indonesia. 2006. Undang-Undang Republik Indonesia Nomor 22 Tahun 2006 Tentang Standar Pendidikan Nasional. Jakarta

Juandi, D. \& Sugilar. 2011. Metode Penelitian Pendidikan Matematika. Jakarta: Universitas Terbuka

NCTM. 2000. Principles and Standarts for School Mathematics.Reaston,VA: NCTM.

Sutawidjaja, A. \& Afgani, J. 2011. Pembelajaran Matematika. Jakarta: Universitas Terbuka.

Syahbana, A. 2012. Peningkatan

Kemampuan Berpikir Kritis Matematis Siswa SMP Melalui Pendekatan Contextual Teaching And Learning. Edumatica Volume 02 Nomor 01 , April 2012. 
e-ISSN 2442-5419 Vol. 5, No. 1 (2016) 61-67

Wiliyati, B. 2012. Peningkatan

Kemampuan Berpikir Kritis

Dan Self-Efficacy Matematis

Siswa SMA Dengan

Menggunakan Pendekatan

Investigasi. Tesis Sekolah

Pascasarjana Universitas

Pendidikan Indonesia.

Bandung. 